\title{
The Effect of Literacy Skills on the Critical Thinking Skills of Mathematics Education Students
}

\author{
Vera Dewi Susanti 1, Ika Krisdiana ${ }^{2}$ \\ DOI: $10.35445 /$ alishlah.v13i1.371
}

\begin{abstract}
Article Info
Abstract

Keywords:

Literacy skills

Critical thinking skills

Mathematics

This study aims to see the effect of literacy skills on students' critical thinking skills. This research type is a correlational study to know the relationship between literacy skills and students' critical thinking skills. The total population is 168 students, and the level of precision is set at $10 \%$. A sample of 63 respondents will be obtained, taken using a simple random sampling technique. The data analysis used in this study is a simple regression analysis with the product-moment correlation coefficient formula. The results showed that literacy skills positively correlate with students' critical thinking skills by $80 \%$. It shows that besides literacy, there are still $20 \%$ of other factors that can affect students' critical thinking skills.
\end{abstract}

Kata kunci:

Kemampuan Literasi

Kemampuan Berpikir

Kritis

Matematika

\begin{abstract}
Abstrak
Penelitian ini bertujuan untuk melihat pengaruh kemampuan literasi terhadap kemampuan berpikir kritis mahasiswa. Jenis penelitian ini adalah penelitian korelasional untuk melihat hubungan kemampuan literasi terhadap kemampuan berpikir kritis mahasiswa. Jumlah populasi adalah 168 mahasiswa dan tingkat presisi yang ditetapkan sebesar 10\%, maka akan diperoleh sampel sebanyak 63 responden, yang diambil menggunakan teknik simple random sampling. Analisis data yang digunakan dalam penelitian ini adalah analisis regresi sederhana dengan rumus koefisien korelasi product moment. Hasil penelitian menunjukkan bahwa kemampuan literasi memiliki korelasi yang positif terhadap kemampuan berpikir kritis mahasiswa sebesar 80\%. Hal tersebut menunjukkan bahwa selain literasi masih ada 20\% dari faktor lain yang dapat mempengaruhi kemampuan berpikir kritis mahasiswa.
\end{abstract}

\section{INTRODUCTION}

The ability to think critically is one thing that needs to be considered to give birth to individuals who can meet global demands. In this era, the increasing recognition and the importance of developing learners' critical thinking is a part of educational aims across the world (M. A. Ab Kadir, 2010; M. Akshir Ab Kadir, 2017; Paul, 1995; Wegerif, R., Li, L., \& Kaufman, 2015). There is increased

\footnotetext{
${ }^{1}$ Universitas PGRI Madiun, Madiun, Indonesia

Email: vera.mathedu@unipma.ac.id

2 Universitas PGRI Madiun, Madiun, Indonesia

Email: ika.mathedu@unipma.ac.id

Vol.13 (1) June, 2021

Received: February 2, 2021; Received in revised form: February 22, 2021; Accepted: February 26, 2021; Available online: March 30, 2021

This is an open access article under a Creative Commons Attribution-NonCommercial-ShareAlike 4.0 International License
} 
recognition of the importance of developing students' critical thinking as part of educational goals worldwide. Critical thinking is critical to be developed and improved.

In the process of critical thinking, things happen like distinguishing sharply, thinking carefully, choosing the best, identifying, evaluating, and developing ideas or ideas for the better. Johnson argues that critical thinking is a pure process of brain activity or mentality that aims to solve problems, make decisions, invite or persuade, analyze an assumption, and conduct scientific research (Johnson, 2007).

The ability to think critically is influenced by several factors, both internal and external factors. International educational policymakers and scholarship stress the importance to increase climate literacy in people, which means supporting their acquisition of specific knowledge and skills to respond to climate change, such as critical thinking and systemic approaches for identifying interrelations of several topics/problems (Bangay \& Blum, 2010; Burandt \& Barth, 2010; Otto et al., 2019). The policy of international education scholars emphasizes the importance of increasing literacy activities to gain knowledge and skills such as critical thinking and systemic approaches to identify the linkages of several topics or problems. It shows that literacy activities can enhance students' critical thinking.

Literacy activities can improve students' critical thinking skills. In today's critical condition, interdisciplinary forms of education can be expanded and achieved if universities pay attention to open and flexible learning ways. (Otto et al., 2019; Teixeira, A., Mota, 2014). According to (Slameto, 2010), some factors influence learning achievement, including internal and external factors. Internal factors include physical, psychological factors (interests, literacy activities, self-regulated learning, etc.) and fatigue factors. External factors include teaching factors, school factors (teaching methods from teachers/lecturers, curriculum, student relations with students, school time, school discipline), and community factors.

Indicators of students' thinking abilities include interpretation, analysis, evaluation, and inference. From these indicators, good literacy skills are needed. Critical thinking in literacy is an indepth activity in evaluating and analytical activities (Pujiono, 2012). Literacy activities are the ability to identify, determine, find, evaluate, create effectively and organized, use and communicate information to overcome various problems. Having literacy skills will have significant growth in critical thinking skills (Kong, 2014). These abilities need to be possessed by each individual to participate in the information society, which is part of fundamental human rights regarding lifelong learning.

The results of the TIMSS (Trends in International Mathematical and Science Study) survey and the Program for International Student Assessment (PISA) shows Indonesia in the bottom ten rankings. From these results, $78 \%$ of Indonesian students can only do questions in the low category, which is only knowing or memorizing. It shows that the material being taught does not emphasize reasoning. If the material being taught does not emphasize reasoning, then; as a result, students lack critical thinking skills (Rahayuni, 2016). Based on observations that have been made, the activities carried out by students of the Education Study Program are very low. It can be seen from the number of library visitors, only $34 \%$ of the total students. Even then, those who mainly visited semester eight worked on their thesis. While learning, many of the students did not record what they had learned. They only photographed the writing on the board. Currently, library and information literacy instruction is one of the most relevant and valued services in academic libraries (Extremeño et al., 2013; Fernández-Ramos, 2019; Long, M. P., \& Schonfeld, n.d.; Wolff, C., Rod, A. B., \& Schonfeld, 2016). It is unfortunate because students do not use the library as a form of literacy activities.

Gherardini, M. (Gherardini, 2016) researched the effect of learning methods and critical thinking skills on scientific literacy skills. His research results state an interaction effect of learning methods with critical thinking skills on scientific literacy skills. In this study, we will review the influence of literacy skills on students' critical thinking skills. Problem-based on the description 
above, the researcher is interested in assessing students' literacy skills in the Mathematics Education Study Program.

\section{METHODS}

This research is quantitative research, including correlational research, namely research intended to determine whether there is a relationship between two or more variables in a study. This type of correlation research is used to find a relationship between two or more independent variables and the dependent variable. Any construct variables can be searched for the relationship in research as long as it is supported by theory. Based on the direction of the relationship, positive and negative relationships are distinguished. Widodo (Widodo, 2009) argues that "based on the number of variables, a single relationship, multiple relationships, multiple relationships, cycle relationships, and path correlation are distinguished."

This research was conducted in the Mathematics Education Study Program of the University of PGRI Madiun with a total population of 168 students and a precision level of 10\%. A sample of 63 respondents was obtained, which were taken using a simple random sampling technique. The instrument used in this study was critical thinking skills test and literacy skills test. The contains literacy skills test contains 30 items, and the essential skills of thinking test contain 25 items. In this study, to assess whether the critical thinking skills test and literacy skills test have the content's validity, the assessment was carried out by the validator. The number of validators in this study was three people. The instrument is said to have good content validity if two or three people put a checkmark on the validation sheet. To calculate the internal consistency of item I, the formula used is the product-moment formula from Karl Pearson, as follows:

$$
r_{x y}=\frac{n \sum X Y-\left(\sum X\right)\left(\sum Y\right)}{\sqrt{\left(n \sum X^{2}-\left(\sum X\right)^{2}\right)\left(n \sum Y^{2}-\left(\sum Y\right)^{2}\right)}} \ldots \ldots \ldots \ldots \ldots . . . . . . . .(B u d i y o n o, 2016)
$$

Information: $r_{x y}=$ internal consistency index for item $\mathrm{i} ; \mathrm{n}=$ the number of subjects who were subjected to a questionnaire; $\mathrm{X}=$ score for item $\mathrm{i}$ (from test subjects); $\mathrm{Y}=$ total score (from trial subjects)

If there are $\mathrm{n}$ items, then the calculation will be done $\mathrm{n}$ times. If the internal consistency index for item $\mathrm{i}$ is less than $\mathbf{0 . 3}$, then it should be discarded. Reliability tests are carried out to see whether the questionnaire items are reliable or not, using the Alpha Formula. The Alpha Formula is:

$$
r_{11}=\left[\frac{n}{n-1}\right]\left[1-\frac{\sum s_{i}^{2}}{s_{t}^{2}}\right]
$$

$$
\text { ..(Budiyono, 2016) }
$$

Information: $\mathrm{r}_{11}=$ instrument reliability index; $\mathrm{n}=$ number of instrument items; $s_{i}^{2}=$ the variance of item-i, i $=1,2,3,4, \ldots, n ; s_{t}^{2}=$ the variance of the trial subjects' scores.

Instruments with a reliability index of more than 0.7 or $r_{11}>0.7$ are only considered good or used in conjunction with a reliability test (Budiyono, 2016). The instrument is said to be reliable, according to (Arifin, 2017). If the correlation number is above 0.60 and less than 1 , then the instrument has a high or reliable correlation. In contrast, if the correlation number is below 0.50, then the instrument has a low or unreliable correlation.

The analysis used in this study is a simple correlation analysis to see the relationship between the independent variable and the dependent variable. This study's dependent variable is the ability of critical thinking expressed in Y. This study's independent variable was expressed in literacy activities X. Simple correlation test was expressed in the formula product-moment correlation coefficient(product-moment). According to (Sugiyono, 2018) there is an influence between the independent and dependent variables if.

Before a simple correlation analysis is carried out, the prerequisite tests are first carried out, namely the normality test, linearity test, and multicollinearity test. The normality test was carried out using the lilliefors method. The sample can come from a normally distributed population 
if Lcount $\leq$ Ltable has a $5 \%$ significance level (Budiyono, 2016). The linearity test was carried out using the $\mathrm{F}$ test to determine whether the variables $X$ and $Y$ in this study had a linear relationship as a condition for regression analysis. The variables $X$ and $Y$ can be linear if Fcount $<$ Ftable (Budiyono, 2016).

A detailed description of your method in conducting research needs to be provided in this section. This section explains how long the research was conducted, population and sample (research targets), data collecting techniques and instrument development, and data analysis. For research using tools and materials, please write down the specifications for the equipment and materials. For qualitative research such as classroom activities, case studies, etc., there should be an increase in the research, research subjects, informants that participate in supporting the research data, location and duration of the research, and details regarding the validity of the research.

\section{FINDINGS AND DISCUSSION}

This study took a sample of 63 students. The single data from each variable is presented in tables 1 and 2.

Table 1. Summary of Data Literacy

\begin{tabular}{ll}
\hline Description & Value \\
\hline Mean & 60,231 \\
Median & 58,492 \\
Modus & 44,000 \\
Variance & 190123,623 \\
Standard deviation & 434,902 \\
\hline \hline
\end{tabular}

Table 1. Summary of Data Literacy

\begin{tabular}{ll}
\hline \hline Description & Value \\
\hline Mean & 62,423 \\
Median & 60,000 \\
Modus & 78,000 \\
Variance & 205642,056 \\
Standard deviation & 476,569 \\
\hline
\end{tabular}

The content validity results indicated that the research instrument had been fulfilled because of the reviewers' criteria' suitability. Testing the literacy instrument on 20 students showed that of the 30 items, 24 items were included in the criteria for an excellent internal consistency index, which was more than 0.3. The instrument is said to be good if it has an internal consistency of more than 0.3, and if it is less than 0.3, then the instrument grain is discarded (Budiyono, 2016; Susanti, 2013). The instrument for measuring literacy skills was used as many as 20 items. Against 20 valid items, this price $r_{11}=0,793$ is obtained means that the instrument is reliable and is used in research. Instruments with a reliability index of more than 0.7 or $r_{11}>0.7$ are only considered good or used in conjunction with a reliability test (Budiyono, 2016).

The results of testing instruments that measure the critical thinking skills of 20 students show that from 25 items, 21 of which are valid criteria. The instrument to measure critical thinking skills used is 20 items obtained this price $r_{11}=0,831$ means the instrument can be reliable so that it can be used in research.

The test requirements that are carried out before testing the hypothesis are the normality test and linearity test. The results of the prerequisite test show that the data is usually distributed and linear. As for the summary, prerequisite test results are presented in Tables 3 and 4. 
Table 3. Summary of Data Normality Test Results Test

\begin{tabular}{lllll}
\hline \hline Equipment & $\mathrm{N}$ & Lcount & Ltable & Conclusion \\
\hline Literacy & 63 & 0,061 & 0,124 & Normal \\
Critical thinking ability & 63 & 0,054 & 0,124 & Normal \\
\hline
\end{tabular}

Table 4. Summary of Linearity Test Results for

\begin{tabular}{lllll}
\hline \hline Independent Variables & Df & Lcount & Ltable & Conclusion \\
\hline Literacy & $1 ; 61$ & 0,856 & 1,670 & Linear \\
\hline \hline
\end{tabular}

After the analysis prerequisite test is met, it is continued to test the hypothesis. Hypothesis testing in this study uses simple regression analysis techniques. The summary of the results of simple linear regression analysis is shown in Table 5 .

Table 5. Summary of Results of Linear Regression Analysis

\begin{tabular}{llllll}
\hline \hline Rcount & rtable & R2xy & Coefficient X & Contanst & Information \\
\hline 0,821 & 0,244 & 0,804 & 37,126 & $\mathbf{2 8 , 7 4 2}$ & Positive \\
\hline \hline
\end{tabular}

Table 5 shows that literacy has a positive correlation with students' critical thinking skills. The analysis results obtained the coefficient of determination $r_{x y}^{2}$ of 0.804 , it means that literacy skills can affect students' critical thinking skills by $80 \%$.

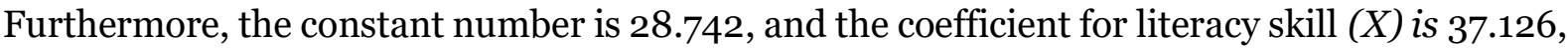
then the regression equation can be stated as follows: $\hat{Y}=37,126+28,742 X$. This equation shows that if literacy skills $(X)$ increase by 1 point, then critical thinking skills are 28.742 . It is also following the results of tests carried out in Siu Cheung Kong's research that students have statistically significant growth in information literacy competencies and critical thinking skills (Kong, S. C., 2014). Besides, there has been a tremendous increase in scientific research related to information literacy (Maddison, T., Doi, C., Lucky, S., \& Kumaran, 2017). Much of this scientific and technical literature focuses on literacy skills of this kind (Koneru, 2010; Nagra, K. A., \& Coiffe, 2010; Oud, 2009; Summey \& Valenti, 2013; Turnbow \& Roth, 2017), examples of particular initiatives (Clapp et al., 2013; Georgas, 2014; Holliday et al., 2006; Webb et al., 2017), reviews of best practices (Blummer \& Kritskaya, 2009; Dewan \& Steeleworthy, 2013; Fernández-Ramos, 2016; Munn \& Small, 2017; Somoza-Fernández \& Abadal, 2009), analysis of their main characteristics (Fernández-Ramos, 2016; Saunders, 2018; Somoza-Fernández \& Abadal, 2009; Yang \& Chou, 2014) or studies about their usefulness (Anderson \& Mitchell, 2012; Fernández-Ramos, 2019; Haber \& Mitchell, 2017; Schweikhard et al., 2018; Weightman et al., 2017).

\section{CONCLUSION}

Literacy skills have a positive correlation with students' critical thinking skills by $80 \%$. It shows that besides literacy, there are still $20 \%$ of other factors that can affect students' critical thinking skills. In this study, the research subject used was still less than 100, and the research was still carried out on 3 rd-semester students of mathematics education at the Universitas PGRI Madiun. For future research, it is hoped that a broader subject will be taken, and items from each instrument can be added. Besides, this study's results should be used to consider the importance of the influence of literacy on students' critical thinking skills so that it is expected to improve student achievement.

\section{REFERENCES}

Ab Kadir, M. A. (2010). Rethinking 'Thinking Schools, Learning Nation': teachers' and students' perspectives of critical thinking in Singaporean education(Unpublished doctoral dissertation). University of Melbourne.

Ab Kadir, M. Akshir. (2017). What Teacher Knowledge Matters in Effectively Developing Critical Thinkers in the 21 st Century Curriculum? Thinking Skills and Creativity, 23, 79-90. 
https://doi.org/10.1016/j.tsc.2016.10.011

Anderson, S. A., \& Mitchell, E. R. (2012). Life after TILT: Building an Interactive Information Literacy Tutorial. Journal of Library \& Information Services in Distance Learning, 6(3-4), 147-158. https://doi.org/10.1080/1533290X.2012.705106

Bangay, C., \& Blum, N. (2010). Education responses to climate change and quality: Two parts of the same agenda? International Journal of Educational Development, 30(4), 359-368. https://doi.org/10.1016/j.ijedudev.2009.11.011

Blummer, B. A., \& Kritskaya, O. (2009). Best Practices for Creating an Online Tutorial: A Literature Review. Journal of Web Librarianship, 3(3), 199-216. https://doi.org/10.1080/19322900903050799

Budiyono. (2016). Metodologi Penelitian Pendidikan. UNS Press.

Burandt, S., \& Barth, M. (2010). Learning settings to face climate change. Journal of Cleaner Production, 18(7), 659-665. https://doi.org/10.1016/j.jclepro.2009.09.010

Clapp, M. J., Johnson, M., Schwieder, D., \& Craig, C. L. (2013). Innovation in the Academy: Creating an Online Information Literacy Course. Journal of Library \& Information Services in Distance Learning, 7(3), 247-263. https://doi.org/10.1080/1533290X.2013.805663

Dewan, P., \& Steeleworthy, M. (2013). Incorporating Online Instruction in Academic Libraries: Getting Ahead of the Curve. Journal of Library \& Information Services in Distance Learning, 7(3), 278-296. https://doi.org/10.1080/1533290X.2013.804020

Extremeño, A., Amante, M. J., \& Firmino da Costa, A. (2013). La Universidad del siglo XXI: nueva docencia, nuevo bibliotecario. Revista Española de Documentación Científica, 36(2), enoo5. https://doi.org/10.3989/redc.2013.2.923

Fernández-Ramos, A. (2016). Factores de éxito en tutoriales en línea de competencias informacionales. Revisión sistemática. Revista Española de Documentación Científica, 39(2), e126. https://doi.org/10.3989/redc.2016.2.1291

Fernández-Ramos, A. (2019). Online information literacy instruction in Mexican university libraries: The librarians' point of view. Journal of Academic Librarianship, 45(3), 242-251. https://doi.org/10.1016/j.acalib.2019.03.008

Georgas, H. (2014). The Implementation of an Independent and Self-Paced Online Library Orientation for Freshman Students and the Use of Sakai as a Quiz Management System (QMS). College \& Undergraduate Libraries, 21(1), 56-75. https://doi.org/10.1080/10691316.2014.877737

Gherardini, M. (2016). Pengaruh Metode Pembelajaran Dan Kemampuan Berpikir Kritis Terhadap Kemampuan Literasi Sains. Jurnal Pendidikan Dasar, 7(2), 253.

Haber, N., \& Mitchell, T. N. (2017). Using Formative \&amp; Summative Assessment to Evaluate Library Instruction in an Online First Year Writing Course. Journal of Library \& Information Services in Distance Learning, 11(3-4), 300-313. https://doi.org/10.1080/1533290X.2017.1324549

Holliday, W., Ericksen, S., Fagerheim, B., Morrison, R., \& Shrode, F. (2006). Instruction in a Virtual Environment. The Reference Librarian, 46(95-96), 187-211. https://doi.org/10.1300/J120v46n95_12

Johnson, E. B. P. D. (2007). Contextual Teaching and Learning. Mizan Learning Center (MLC).

Koneru, I. (2010). ADDIE: Designing web-enabled information literacy instructional modules. Desidoc Journal of Library \& Information Technology, 3o(3), 23-34.

Kong, S. C. (2014). Developing information literacy and critical thinking skills through domain knowledge learning in digital classrooms: An experience of practicing flipped classroom $\begin{array}{llll}\text { strategy. Computers and } \quad \text { Education, } & \text { 160-173. }\end{array}$ https://doi.org/10.1016/j.compedu.2014.05.009

Long, M. P., \& Schonfeld, R. C. (n.d.). Ithaka $S+R$ US library survey 2013. Retrieved from. 
http://www.sr.ithaka.org/sites/default/files/reports/SR_LibraryReport_20140310_o.pdf.

Maddison, T., Doi, C., Lucky, S., \& Kumaran, M. (2017). Literature review of online learning in academic libraries. In T. Maddison, \& M. Kumaran (Eds.). Chandos Publishing.

Munn, J., \& Small, J. (2017). What is the Best Way to Develop Information Literacy and Academic Skills of First Year Health Science Students? A Systematic Review. Evidence Based Library and Information Practice, 12(3), 56. https://doi.org/10.18438/B8QS9M

Nagra, K. A., \& Coiffe, D. J. (2010). Management of online tutorials: A model for a stepby-step approach. Journal of the Library Administration \& Management Section, 7(1), 5-17.

Otto, D., Caeiro, S., Nicolau, P., Disterheft, A., Teixeira, A., Becker, S., Bollmann, A., \& Sander, K. (2019). Can MOOCs empower people to critically think about climate change? A learning outcome based comparison of two MOOCs. Journal of Cleaner Production, 222, 12-21. https://doi.org/10.1016/j.jclepro.2019.02.190

Oud, J. (2009). Guidelines for effective online instruction using multimedia screencasts. Reference Services Review, 37(2), 164-177. https://doi.org/10.1108/00907320910957206

Paul, R. (1995). Critical thinking: how to prepare students for a rapidly changing world California. Foundation for Critical Thinking.

Pujiono, S. (2012). Berpikir Kritis dalam Literasi Membaca dan Menulis untuk Memperkuat Jati Diri Bangsa. Jurnal Pendidikan Dan Pembelajaran, 3(7), 778-783.

Rahayuni, G. (2016). Hubungan Keterampilan Berpikir Kritis Dan Literasi Sains Pada Pembelajaran Ipa Terpadu Dengan Model PBM Dan STM. Jurnal Penelitian Dan Pembelajaran IPA, 2(2), 131. https://doi.org/10.30870/jppi.v2i2.926

Saunders, L. (2018). Information Literacy in Practice: Content and Delivery of Library Instruction Tutorials. The Journal of Academic Librarianship, 44(2), 269-278. https://doi.org/10.1016/j.acalib.2017.12.022

Schweikhard, A. J., Hoberecht, T., Peterson, A., \& Randall, K. (2018). The Impact of Library Tutorials on the Information Literacy Skills of Occupational Therapy and Physical Therapy Students in an Evidence-Based Practice Course: A Rubric Assessment. Medical Reference Services Quarterly, 37(1), 43-59. https://doi.org/10.1080/02763869.2018.1404388

Slameto. (2010). Belajar dan Faktor yang mempengaruhinya. Rineka Cipta.

Somoza-Fernández, M., \& Abadal, E. (2009). Analysis of web-based tutorials created by academic libraries. The Journal of Academic Librarianship, 35(2), 126-131. https://doi.org/10.1016/j.acalib.2009.01.010

Summey, T. P., \& Valenti, S. (2013). But We Don't Have an Instructional Designer: Designing Online Library Instruction Using ISD Techniques. Journal of Library \& Information Services in Distance Learning, 7(1-2), 169-182. https://doi.org/10.1080/1533290X.2012.705630

Teixeira, A., Mota, J. (2014). A Proposal for the Methodological Design of Collaborative Language MOOCs. Providing Learning, Transcending Boundaries.

Turnbow, D., \& Roth, A. (2017). Engaging Learners Online. In Distributed Learning (pp. 123-134). Elsevier. https://doi.org/10.1016/B978-0-08-100598-9.00007-6

Webb, J., Logan, J., \& Flaccavento, M. (2017). Delivering Synchronous Online Library Instruction at a Large-Scale Academic Institution. In Distributed Learning (pp. 157-175). Elsevier. https://doi.org/10.1016/B978-0-08-100598-9.00009-X

Wegerif, R., Li, L., \& Kaufman, J. (2015). The Routledge International Handbook of Research on TeachingThinking. UK: Routledge.

Weightman, A. L., Farnell, D. J. J., Morris, D., Strange, H., \& Hallam, G. (2017). A Systematic Review of Information Literacy Programs in Higher Education: Effects of Face-to-Face, Online, and Blended Formats on Student Skills and Views. Evidence Based Library and Information Practice, 12(3), 20. https://doi.org/10.18438/B86W9o

Widodo, T. (2009). Metode Penelitian Kuantitatif. Surakarta LPP UNS dan UNS Press.

Wolff, C., Rod, A. B., \& Schonfeld, R. C. (2016). Ithaka S+R US Faculty Survey 2015. Retrieved from. 
http://www.sr.ithaka.org/publications/ithaka-sr-us-faculty-survey2015/

Yang, S. Q., \& Chou, M. (2014). Promoting and Teaching Information Literacy on the Internet: Surveying the Web Sites of 264 Academic Libraries in North America. Journal of Web Librarianship, 8(1), 88-104. https://doi.org/10.1080/19322909.2014.855586 